\title{
Sistema internacional com hegemonia das democracias de mercado: desafios de Brasil e Argentina*
}

THIAGO GEHRE GALVÃO**

Um duro retrato da realidade internacional: esta talvez seja a frase que melhor sintetiza o livro de Eduardo Viola, professor titular de Relações Internacionais da Universidade de Brasília, e Héctor Ricardo Leis, professor da Universidade Federal de Santa Catarina. Após quase vinte anos do colapso da União Soviética as transformações operadas no sistema internacional agora podem ser melhor percebidas: coube aos autores descrevê-las de forma coerente e contundente. A linha central de pensamento dos autores é que o sistema de estados que delineia a ordem internacional vigente é baseado na hegemonia das democracias de mercado. Nesse sentido, o protagonismo norte-americano só é válido em composição com outras grandes potências: juntas, como democracias de mercado consolidadas, fazem da democracia seu modelo político, do capitalismo de mercado sua moldura econômica definidora e da globalização seu veículo de manutenção ou transformação da ordem vigente. Ainda que exaltando o verdadeiro liberalismo, a análise de ambos aponta para uma valorização do progresso social e econômico como metas universais, em detrimento de orientações puramente ideológicas.

O objetivo da obra é o de apresentar ao leitor inteligente um retrato realista da cena internacional do século 21 , desenhada não por incertezas e bifurcaçōes, nem por antagonismos de classes e forças sociais, mas pela certeza da preponderância do liberalismo em construir um mundo em consonância com as demandas sociais e com o objetivo de preparar as novas geraçôes para lidar com a infinidade de velhos e novos desafios deste milênio, como terrorismo, pobreza e desigualdades globais, epidemias e problemas ecológicos (poluição, desflorestamento, escassez de água...).

Para tanto, os autores dividem a obra em três partes principais com cinco capítulos: tratam da rota de Brasil, Argentina e América do Sul rumo ao universo pós-histórico das democracias de mercado. No primeiro capítulo, O sistema internacional com hegemonia das democracias de mercado no início do século XXI, os

\footnotetext{
** VIOLA, Eduardo \& LEIS, Héctor Ricardo. Sistema internacional com hegemonia das democracias de mercado: desafios de Brasil e Argentina. Florianópolis: Insular, 2007, 232 p., ISBN: 978-85-7474-339-4.

** Professor de Relaçóes Internacionais da Universidade Federal de Roraima - UFRR e doutorando em Relações Internacionais pela Universidade de Brasília - UnB (thiago.gehre@gmail.com).
} 
autores se dedicam coerentemente a um esforço de conceitualização das principais categorias explicativas que subsidiam o argumento do livro, como globalização, sociedade do conhecimento, regime político e política exterior. Além disso, produzem um panorama do mundo no início do ano de 2007, numa preocupação de analisar a conjuntura atual das relaçôes internacionais.

O segundo capítulo Brasil: modernização lenta e travada de uma sociedade de corte é dedicado a explicar, a partir do perfil sócio-político brasileiro, os entraves ao desenvolvimento nacional. Para os autores, o tipo de relação pessoal de privilégio e segregação promovido pelas elites nacionais é nefasto para as pretensões nacionais de potência, uma vez que "a lentidão do Brasil cobra um forte preço em termos de prosperidade e oportunidades" (p. 79).

Argentina: modernização parcial e retrocessos cíclicos de uma sociedade movimentista, terceiro capítulo da obra, discute a realidade do principal vizinho brasileiro e coloca em evidência a montanha russa histórica que representa o passado do país em sua investida internacional. Diferentemente do Brasil, marcado por uma lenta progressão no seu processo de desenvolvimento, a Argentina teve sua história marcada por rupturas e retrocessos que foram fatais em colocar o país numa situação periférica e de subdesenvolvimento. Esse descaminho histórico é promovido por movimentos (sociais, ideológicos, nacionalistas) que minam e corroem as bases da fortaleza institucional democrática.

Os capítulos quatro e cinco delimitam uma terceira parte da obra, na qual Viola e Leis ajustam o foco de análise para abarcar o todo sul-americano. No quarto capítulo, América do Sul e suas alternativas de integração, e no quinto, O dilema da América do Sul no século XXI: democracia de mercado com estado de direito ou populismo, os autores apontam para a trajetória declinante da região. Com exceção do Chile, bem sucedido nas reformas políticas e econômicas de liberalização, os outros países apresentam resultados pífios: a estagnação uruguaia, a orientação nortista do Peru, a peculiaridade colombiana (crescimento econômico e crise política interna), a constante instabilidade do Equador, a decadência política e social da Venezuela, a Bolívia como um país a beira da desintegração, o Paraguai como um precursor de Estado fracassado e Guiana e Suriname como portas de entrada dos ilícitos transnacionais. Além disso, na visão dos autores, o Brasil se perde na sua cruzada pela liderança regional, uma vez que a "principal potência da 'América do Sul' são os EUA, e não o Brasil". O dilema sul-americano evidencia-se do encontro entre populismo e democracia: será o populismo capaz de gerar verdadeiras democracias de mercado? Para Viola e Leis a resposta é óbvia: o populismo só tende a esfacelar as sociedades em fatias irreconciliáveis!

Por um lado, a obra de Viola e Leis apresenta pequenos desvios: por ser uma análise essencialmente conjuntural incorre nas dificuldades inerentes a este tipo de abordagem, como não conseguir enxergar tendências de longa duração, nem acompanhar as modificações recentes da vida política doméstica e internacional. Por outro, compensa pela riqueza analítica e conceitual, contribuindo 
decisivamente para o campo de estudo das Relaçôes Internacionais ao disseminar uma visão de mundo condizente com os anseios e expectativas de sociedades em desenvolvimento, como a brasileira e a argentina. Ademais, os autores apresentam colocações contundentes e afirmativas acerca da inserção de Brasil e Argentina em um mundo democrático desenvolvido, posicionando-se objetivamente em determinado locus do mundo das idéias. Por exemplo, afirmam que "o maior paradoxo do Brasil é produzir exclusão social em nome da inclusão” (p. 79) ou que "o futuro da Argentina parece ser o eterno retorno do movimento e a contínua decadência do país em ciclos de euforia e de depressão" (p. 171).

Viola e Leis apontam em seu livro para o surgimento de novas esperanças para os medos e ameaças da vida internacional após o colapso soviético e após os atentados terroristas de 11 de setembro de 2001. Em um novo mundo, no qual sobressai a figura do império norte-americano, desenvolvem a análise com base em um argumento maduro, longe de representar uma visão ingênua ou doutrinária sobre o papel dos EUA no mundo. Isto torna a obra uma referência para debates e discussões dentro do campo de relações internacionais, bem como em outras áreas conexas, algo pouco estimulado na academia brasileira. Além disso, conceitualmente, o livro avança ao apontar uma nova forma de compreender a distribuição de poder no mundo: não a partir de uma sociedade internacional global ou um espaço mundial, nem uma ordem unipolar ou unimultipolar - os autores falam de um sistema de hegemonia das democracias de mercado.

Em suma, os autores vislumbram um novo arranjo nas relaçôes internacionais do século 21, semelhante ao surgido no início do século 19 na Europa. Duzentos anos depois, estaria emergindo um concerto democrático capitalista de mercado para ditar o ritmo da ordem internacional pós-guerra fria. Conforma-se, na visão dos autores, uma poliarquia democrática capitalista mundial para regular uma nova ordem em direção à homogeneização política e econômica. Por isso, a obra de Viola e Leis deve ser lida como uma lúcida saudação à era das democracias de mercado. 